O dopuschenii lits, 1913 - O dopuschenii lits zhenskogo pola k sluzhbe po uchebno-vospitatelnoy chasti v selskohozyaystvennyih uchebnyih zavedeniyah. Vyisochayshe utverzhdennyiy odobrennyiy Gosudarstvennyim sovetom i Gosudarstvennoy dumoy zakon 30 iyunya $1913 \mathrm{~g}$. [On the admission of females to the educational service in agricultural educational institutions. The highest approved law approved by the State Council and the State Duma on June 30, 1913] // PSZRI. Sobranie trete. T. 33. Ch.1. SPb., 1913. 1561 s. [in Russian]

Obzor, 1898 - Obzor deyatelnosti Ministerstva Zemledeliya i Gosudarstvennyih Imuschestv za 4-y god ego suschestvovaniya (30 marta 1897g. - 30 marta 1898 g.) [Review of the activities of the Ministry of Agriculture and State Property for the 4th year of its existence (March 30, 1897 - March 30, 1898)]. SPb., 1898. 300 s. [in Russian]

Polozhenie, 1895 - Polozhenie o selskohozyaystvennoy i promyishlennoy vyistavke, ustraivaemoy Kievskim obschestvom selskogo hozyaystva i selskohozyaystvennoy promyishlennosti v Kieve v 1898 [Regulations on the agricultural and industrial exhibition organized by the Kiev Society of Agriculture and Agricultural Industry in Kiev in 1898]. g. Kiev, 1895. 8 s. [in Russian]

Polozhenie, 1900 - Polozhenie o selskohozyaystvennyih remeslennyih uchebnyih masterskih. Vyisochayshe utverzhdennoe 10 marta $1897 \mathrm{~g}$. [Regulation on agricultural craft training workshops. Highest approved on March 10, 1897] // PSZRI. Sobranie trete. T. XVII. 1897. SPb., 1900. 1562 s. [in Russian]

Polozhenie, 1904 - Polozhenie o selskohozyaystvennom obrazovanii. Vyisochayshe utverzhdennoe 26 maya 1904 goda [Regulation on agricultural education. Highest approved on May 26, 1904]. // PSZRI. Sobranie trete. T. XXIV, 1904. SPb., 1907. 1257 s. [in Russian]

Pravila, 1898 - Pravila dlya uchenits i slushatelnits Zozulinskoy zhenskoy prakticheskoy shkolyi [Rules for pupils and students of the Zozulinskaya women's practical school] // Sbornik svedeniy po selskohozyaystvennomu obrazovaniyu. Vyip. 1. Zhenskoe obrazovanie. SPb., 1898. S. 179-188. [in Russian]

Sbornik, 1900 - Sbornik svedeniy po selskohozyaystvennomu obrazovaniyu [Collection of information on agricultural education]. Vyip. IV. Selskohozyaystvennyie uchebnyie zavedeniya po svedeniyam k 1 yanvarya 1898 goda. SPb., 1900. 195 s. [in Russian]

Sbornik, 1910 - Sbornik svedeniy po selskohozyaystvennomu obrazovaniyu [Collection of information on agricultural education]. Selskohozyaystvennyie uchebnyie zavedeniya v 1910 godu. SPb. Vyip. XVI, 1910. 188 s. [in Russian]

Sorokina, 2019 - Sorokina T.A. Stanovlenie seti nizshih selskohozyaystvennyih shkol v Kurskoy gubernii v kontse XIX - nachale XX veka [Formation of a network of lower agricultural schools in the Kursk province in the late XIX - early XX centuries] // Uchenyie zapiski. Elektronnyiy nauchnyiy zhurnal Kurskogo gosudarstvennogo universiteta, 2019. № 2 (50). T. 1. URL: https://cyberleninka.ru/article/n/stanovlenie-seti-nizshihselskohozyaystvennyh-shkol-v-kurskoygubernii-v-kontse-xix-nachale-xx-veka/viewer [in Russian]

Terletska, 2013 - Terletska U.I. Poshyrennia silskohospodarskykh znan za dopomohoiu chytan i besid u Chernihivskii hubernii naprykintsi XIX - na pochatku XX stolittia [Expansion of the Silk-dweller's knowledge for additional reading and conversation in the Chernigiv province for example in the XIX - on the ear of the XX century] // Visnyk Chernihivskoho natsionalnoho pedahohichnoho universytetu, 2013. Vyp. 110. Pedahohichni nauky. S. 102-104. [in Ukrainian]

Tretyakov, 2017 - Tretyakov A.V. Obrazovatelnoe selskohozyaystvennoe zakonodatelstvo poreformennoy Rossii rezultat reform $60-70$-h godov XIX v. [The educational agricultural legislation of post-reform Russia is the result of the reforms of the 60s - 70s of the XIX century] // Bereginya. 777. Sova: obschestvo, politika, ekonomika. № 4 (35). S. 18-26. [in Russian]

Trudyi, 1879 - Trudyi komissii po sostavleniyu proekta (Polozheniya o Nizshih selskohozyaystvennyih shkolah) [Proceedings of the Drafting Commission (Provisions on Lower Agricultural Schools]. SPb, 1879. 160 s. [in Russian]

УДК 902/904 (477 - 474.5) (477.72)

Свімлана БІЛЯЕВА

orcid.org/0000-0003-7619

доктор історичних наук, професор кафедри всесвітньої історії та методик навчання

Уманського державного педагогічного університету імені Павла Тичини

(Україна, Київ) svitbil@ukr.net

\title{
3 ІСТОРІЇ СТВОРЕННЯ ФОРТИФІКАЦІЙНОЇ ЛІНІЇ ВЕЛИКОГО КНЯЗІВСТВА ЛИТОВСЬКОГО І РУСЬКОГО У ПІВНІЧНОМУ ПРИЧОРНОМОР'ї
}

Історико-археологічне вивчення маловідомого періоду перебування украӥнських земель у складі Великого князівства Литовського і Руського : розбудови фортецьь, організації транснаціональної торгівлі, матеріальної 
культури є актуальним завданням сучасного етапу наукових досліджень. Завдяки археологічним розкопкам останніх 2016-2021pp. зроблені видатні відкриття у галузі вивчення колплексу пам'яток Південної фортифікачійної лінії, які засвідчують наявність спільної історичної спадщини Литви і України у Північному Причорномор $\dddot{\imath}$.

У статті показано, щуо дослідження 2016-2021 рр. довели надзвичайну важливість вивчення археологічних пам'яток українських земель доби середньовіччя у Північному Причорномор $і ̈$. Знаковим відкриттям, визнаним українською та світовою спільнотою, постало створення доказової бази існування будівельних залишків фортеці Тягинь, архітектурно-археологічних об'єктів та ознак литовської присутності. Ї̈ розташування на крайньому Півдні території Великого князівства Литовського та Руського уособлювало важливий форпост захисту украӥнських земель, важливого чинника створення передумов становлення нового суспільного стану козацтва та його використання у захисті батьківщини.

Ключові слова: система укріплень, фортечя Тягин, археологічні дослідження, фортифікачійна лінія, Північне Причорномор'я.

Svitlana BILIAIEVA

doctor of History, Professor of

World History and metodic of studing Department

Uman State Pedagogical

University named Paul Tyczyn

(Ukraine, Uman)

svitbil@ukr.net

\section{FROM HISTORY OF CREATION OF THE FORTIFICATION'S LINE OF THE GREAT PRINCIPALITY OF LITHIANIANA AND RUSS IN THE NORTH BLACK SEA AREA}

Historical and archaeological study of the little-known period of Ukrainian lands in the Grand Duchy of Lithuania and Russia: fortresses, organization of transnational trade, material culture are the actual task of the modern stage of scientific research. Thanks to the archaeological excavations of the last 2016-2021y. outstanding discoveries in the field of studying the complex of monuments of the Southern Fortification Line were made, which testify to the existence of a common historical heritage of Lithuania and Ukraine in the Northern Black Sea coast. The main sense of the article - presentation of the latest discoveries, which have received recognition in Ukraine and in the world.

The researches, conducted in 2016-2021, proved crucial importance of the study of the archeological monuments of the Ukrainian lands of the Middle Ages in the Northern Black Sea Region. A significant discovery, recognized by Ukrainian and world community, was the formation of an evidence base for the existence of the construction remains of the fortress Tyagin, architectural and archeological objects and the signs of Lithuanian presence. Its location in the extreme South of the Grand Duchy of Lithuania and Rus' was an important outpost for the protection of Ukrainian lands, a significant factor in the creation of preconditions for the formation of a new social state of the Cossacks and its use for homeland defense. As a vital historical and cultural, socio-political phenomenon the fortress is of considerable interest for the study of little-known pages of the Middle Ages: the history of LithuanianRus'statehood, the Crimean Khanate, the Italian cities - Genoa and Venice in the Black Sea, the contacts between the Ottoman Empire and the Ukrainian Cossacks. All these crucial and fateful periods of Ukrainian history are among relevant research issues of nowadays and are to be studied.

Key words: system of fortification, fortress Tyagin, archaeological investigartion, fortification's line, North Black Sea area.

Постановка проблеми. Важливим періодом в історії України $\epsilon$ час існування федеративної держави - Великого князівства Литовського, Руського та Жемайтійського. Сформувавши державу, одержавши перемогу у протиборстві 3 татарами у битві при Синіх Водах 1362 р., литовські князі намагалися створити потужну систему фортифікації південного прикордоння $\mathrm{i}$ при цьому забезпечити транснаціональну торгівлю, функціонування митниць та переправ. Проте, історія створення фортифікаційної лінії у Північному Причорномор'ї залишається мало дослідженою ланкою історії України і Литви, і водночас іiї вивчення $\epsilon$ надзвичайно актуальною проблемою на етапі створення нової історії країн, що протягом тривалого часу були позбавлені можливості 
розробки багатьох питань взаємодії Литви та Південноруських князівств, реконструкції цивілізаційного процесу у південному регіоні Великого князівства Литовського і Руського. Тому, нагальним завданням сучасного етапу $\epsilon$ історико-археологічне вивчення системи фортифікації, розбудови фортець, організації транснаціональної торгівлі, і водночас, всіх особливостей політичних, економічних і етнокультурних засад, що були притаманні цьому етапу існування федеративної державності Литви і України.

Аналіз досліджень. Будівельна діяльність литовських князів другої половини XIV ст. охопила велику за протяжністю територію із Заходу на Схід, що знайшло своє відображення у писемних джерелах та матеріальних залишках. Проте, в історії України цей період протягом тривалого часу залишався мало вивченим, а цілеспрямовані археологічні дослідження майже не проводились. На сьогодні не визначені всі пункти побудови фортець, хоча у «Списках руських міст далеких і близьких» (Тихомиров, 1978: 83-137), який був створений наприкінці XIV ст. серед литовських міст зазначені і деякі містафортеці.

Виклад основного матеріалу. На західному боці ПівнічноПричорноморського ареалу до складу Великого князівства Литовського після розгрому татар у битві при Синіх Водах 1362 р. та остаточного припинення правління джучидських ханів наприкінці 1360-1370 pp. увійшов Білгород на Дністрі, як «ключ Литви», чому литовська влада надавала надзвичайного значення. Можливо, нетривале правління литовського князя Юрія Коріатовича до кінця 1374-1375 pр., співпадало із просуванням кордону Литви до Дністра (Шлапак, 2004: 26). На східному напрямку від Білгороду на Дніпро-Бузькому лимані відома литовська фортеця Дашів (Очаків). Надзвичайний інтерес викликає фортифікаційна діяльність Великого князя Вітовта із облаштування Південно-Східного кордону держави із Золотою Ордою, де, можливо, був сформований цілий комплекс укріплень, кожне з яких знаходилося на відстані 20 км від іншого. Мова іде про вежу Вітовта, форт(?) Бургунка та фортецю Тягин.

Місто-фортеця на острові та переправа неодноразово згадуються у багатьох історичних джерелах XV-XVIII ст. Але, відносно часу його заснування та самих засновників, відомі різні версії. Існує і певна плутанина із назвами пунктів, що пов'язуються із Тягинем, Тягинською фортецею, переправою та митницею.

У писемних джерелах збереглися різні згадки щодо історії Тягинського комплексу (городища та фортеці), які $є$ сучасними 3 різними етапами його існування та більш пізніх часів. Найбільш давніми $є$ розрізнені повідомлення німецьких хроністів Йогана фон Посільге, автора «Хроніки землі Прусської», Дітмара $з$ Любека та Йогана Руфуса, з яких складається загальна інформація щодо походів князя Вітовта і навіть побудови ним замку з каменю та глини на Дніпрі на відстані 200 миль від Вільнюса (Жарких, 2017).

3 джерел XVI ст. заслуговують на увагу повідомлення мандрівників, серед них: Жильбер де Ланнуа та Михалон Литвин. Останній у 1544 році був делегований сеймом (при королі Сигизмунді I) для опису замків у Литві i 
Україні. М. Литвин доповідав, що біля Таванського перевозу на Дніпрі купці, які йшли 3 караванами з Кафи, платили в давнину предкам його величності, тобто королю Польщі, велике мито. I дотепер, відмічав М.Литвин, «ще $е$ кам'яна палата із склепінням, яку звуть і поляки, і таврійці, і греки Вітовтової баней» (balneum Vitovdinum, в подлиннике Vitordinum). В ній, кажуть, жили митники великого князя Литовського, які збирали мито (Архів, 1854: кн.2, 67).

Є деякі свідчення 3 середини XVII ст. турецького мандрівника Евлія Челебі (Челебі, 1961). Крім того, варті уваги свідчення 3 XVIII-XIX ст.: С. I. Мишецького 1740 р., Жана-Бенуа Шерера 1788 р., Ф. Ф. Ласковського 1865 р., О. С. Афанасьєва-Чужбинського 1860 р., які дають можливість переконатися у досить тривалому існуванні залишків фортеці та її забудови, що підкреслює достатньо потужну забудову, планування, конструкції та матеріал будівництва.

Відомості станом на 1740 р. презентовані у праці інженера-підпоручика C.I. Мишецького, виданій у 1847 р., й присвячений історії запорізьких козаків. Він називає важливі для історії та сучасного дослідження комплексу городища та фортеці. Автор відмічає місцезнаходження руїн (при річці Тягинці) біля самого Дніпра; надає опис комплексу: «велике містечко Тягинка і при ньому трикутний замок з круглими вежами, оточений водою»; інформує про розміри пам'ятки (довжиною у версту, а шириною понад півверсти), що фундамент містечка, ймовірно, стін за периметром, кам'яний. Він вказує, що будівничими були «давні німецькі народи-франкі», і що у 1738 р. замок був відбудований росіянами. (Мишецький, 1847: 33). Відзначимо, що вказане планування фортеці (трикутне) збігається із сучасними даними аерофотозйомки. Також відповідає і місце знаходження замку та природні умови розташування; матеріал будівництва - камінь. Але С. І. Мишецький бачив замок більш пізнього часу, так як він згадує круглі вежі, тоді як нами виявлено прямокутну вежу, що цілком відповідає ранньому періоду кам'яного замкового будівництва. Наприклад, у Кревському замку кутова вежа виходить за межі периметра стін, як і Тягинська, і має форму прямокутника (Красножон, 2018: 100, іл.48). Це й прямокутні більш ранні вежі, що передували круглим вежам цитаделі БілгородДністровської фортеці, також трикутної за планом. До того ж найбільш раннє зображення фортеці у Кодексі Латинус Парисинус XIV ст. саме 3 прямокутними вежами (Шлапак, 2001: 18, іл.2).

Невеличка згадка французького аташе і історика Ж.- Б. Шерера 1788 p практично співпадає з текстом С.I Мишецького, що, ймовірно, було пов'язане 3 пізнішою вставкою попереднього тексту.

3 картографічних джерел важлива «Карта Литви» М. Радзівілла 1613 р., до якої додається карта ділянки нижньої течії Дніпра. Доволі точно передано на карті рельєф берегів, позначено острови та притоки. На карті також позначено місто-фортеця «Теhinka». На відміну від Тавані, що теж позначена на цій карті під назвою «Semimaiki», Тягинка - не руїни, а існуючий населений пункт. Зовсім ніяких сумнівів не викликає локалізація фортеці «Tehinka» на острові Велике городище. Їй відповідає пам'ятка археології фортеця Тягин. На мініатюрі бачимо невелику фортецю з масивною круглою баштою, оздобленою 
зубцями, та масивну будівлю основної частини фортеці, ймовірно цитадель квадратної форми, яку досліджував В.І. Гошкевич. При цьому знову відмітимо, що ми бачимо зображення фортеці після певних перебудов, які мали місце до початку XVII ст. - часу створення карти.

«Загальна карта України» Гійома де Боплана 1648 р. та «Карта Польщі» Дж. А. Річчі Занноні 1767 р. надають можливість краще зрозуміти історичну географію нижнього Дніпра. Річка Тягинка та городище біля неї згадується і в російській «Книзі Великого креслення », яка датована 1627 роком.

На карті XVII ст. «Typus generalis Ukrainae», між Бургункою та Тягинкою зазначені два замка, один з яких названий «Balneum Vitoldi» (Эварницький, 1896: 128). На карті Річчі Занноні, але вже 1767 р., на протилежному березі Дніпра навпроти правобережного укріплення с. Тягинки вказане татарське селище Ескі Тавань (Стара Тавань) (Дяченко, 2004: 63).

У Коментарі до книги Й.Х. Енгеля «Історія України та українських козаків» відзначено, що Тягиня (Тягин) - турецька фортеця і місто у гирлі Дніпра, були засновані, імовірно, генуезцями у XIII-XV ст. Фортеця перебудована турками у 1492 р. (Енгель, 2014: 542). Д.І. Яворницький, у працях якого неодноразово згадується Тягинська переправа, не згадував про литовське походження фортеці й, навпаки, відмічав, що у 1491 р. татари побудували фортецю Тягинь (Яворницький, $1990: 322$ ).

Археологічне вивчення пам'ятки поблизу с. Тягинка розпочалося в 1914 р. зберігачем Херсонського музею В. І. Гошкевичем, який визначив наявність різних культурних нашарувань, зокрема античних (Гошкевич, 1916: 3-12). Він вперше репрезентував топографічний план острова, приділив велику увагу дослідженню архітектурно-будівельних залишків та системі фортифікації на тереторії острова в цілому. Ним зафіксовані залишки валу та рову, укріплень у формі рівнобедреного трикутника (з трьох частин), три будівлі 3 вапняку, одна - оздоблена прямолінійними барельєфами, залишки пічки, побудованої 3 сирцевої цегли, яка широко застосовувалася на багатьох пам'ятках часів Золотої Орди. Усі споруди, крім будинку А, за нумерацією В. І. Гошкевича, були розташовані у внутрішньому просторі. Стіни укріплень і самі будівлі були складені з вапняку, мали приблизно однакову товщину - 0,8 м та побудовані в однаковій конструктивній манері (Гошкевич, 1916: 5-7). На думку B. I. Гошкевича, середньовічні матеріали пам'ятки вкладаються у межі XIVXVI ст. і мають, зокрема, кераміку сграфіто відкритих форм, як наприклад, миски. Він вважав укріплення литовським замком та митницею і ототожнював залишки укріпленого замку, відкритого ним на острові із митницею, побудованою на початку XV ст. великим князем литовським Вітовтом на самому кінці королівського шляху, який тягнувся з Подолії, через Буг, до p. Дніпра, який тоді був рубежем литовсько-польских та татарських володінь. Проаналізувавши писемні джерела, В.І.Гошкевич дійшов до висновку, що існування Вітовтової митниці було нетривалим. Це підтверджує і свідчення М. Литвина, яке відноситься до середини XVI ст. Крім того, В. І. Гощкевич звертає увагу на те, що в кінці XV ст. (а саме у 1491 р.) Менглі Гірей заснував укріплення - Тягинку. До цього часу політична ситуація значно змінилась $\mathrm{i}$ 
Дніпро перестав бути кордоном литовсько-польської держави, а отже і митниця опинилася серед татарських володінь, а відтак втратила свою актуальність i припинила своє існування.

В. І. Гошкевичем були зафіксовані ознаки руйнації фортеці під час військових дій. Серед них: вісім кам'яних гарматних ядер, залізні черешкові наконечники стріл, сліди великої пожежі, попіл від якої вкривав підмури стін та складав верхній шар глиняної підлоги (Гошкевич, 1916: 5-8).

На відстані понад 1 км на північний схід від укріплень, В.І. Гошкевичем був досліджений курганний могильник з невисокими насипами. Розкопані 12 насипів, у яких було відкрито 15 поховань чоловіків. За знахідками двох сердолікових намистин, форма яких характерна для XV ст. автор визначив, що могильник $є$ синхронним будівельним спорудами і датується тим самим часом (Гошкевич, 1916: 10).

В. I. Гошкевич вважав надзвичайно важливим продовження розкопок пам'ятки, але цього не вдалось зробити. Матеріали досліджень увійшли до колекції Херсонського краєзнавчого музею.

Подальше вивчення пам'ятки було продовжено у 1936 році, коли директором Херсонського краєзнавчого музею С.О. Секретним були виявлені культурні залишки біля с. Тягинки. Насамперед, визначена наявність городища, оточеного валом на городищі, на площі якого знайдена кераміка різних історичних періодів від античності до середньовіччя. Було заплановано зробити декілька шурфів наступного року. Важливим результатом розвідки є також підготовлена схематична карта археологічних об'єктів біля с. Тягинка*

Розвідки на тереторії пам'ятки були здійсненні у 1977 p. M.І. Оленковською (Абікуловою) та Н. П. Оленковським. Ними була обстежена Тягинська балка, яка впадає у р. Дніпро біля с. Тягинка. У гирлі балки були знайдені уламки амфор та ліпного посуду V-VI ст., що засвідчує наявність матеріалів давньогрецького часу, та середньовічне пряслице 3 рожевого шиферу. Крім того, на правому березі балки на невеличкому мисі було відкрито поселення доби пізньої бронзи (Оленковская, Оленковский, 1978: 364).

Розвідка та розкопки проводились у 1992-1993 pp. Тягинською археологічною експедицією під керівництвом С.В. Бахматова. В результаті робіт колекцію Херсонського музею було поповнено керамікою із зеленою поливою, аналогічною знайденій на татарському поселенні Любимівського городища. О.Д. Чорная видала стислу публікацію колекції полив'яної кераміки Херсонського краєзнавчого музею, зокрема з розкопок В.I. Гошкевича на Тягинці (Чорная, 1998: 186-189). Авторка висловила думку, що за часів литовського князя Вітовта на початку XV ст. збудували митницю біля старої Таванської переправи на кордоні між Великим князівством Литовським та татарськими володіннями. Але із зміною історичної ситуації, посиленням Кримського ханства, кордони польсько-литовської держави були посунуті на

\footnotetext{
* Висловлюємо щиру подяку А. Лопушинському за копію рукописних матеріалів 3 історії досліджень Херсонського краєзнавчого музею у 1936 р.
} 
північ. По берегах Дніпра будувалися турецькі та татарські фортеці. Особливо активну діяльність з розбудови фортець розгорнув хан Менглі Гирей. В тому числі за часів хана Менглі-Гирея у 1491 р. була побудована Тягинська фортеця у районі так званої «Вітовтової митниці», на яку вказував В.І. Гошкевич (Гошкевич, 1916:10). Нагадаємо, що у 1492 р. містечко Менглі Гірея в Очакові також було побудовано на місті старої фортеці. Проте, досі остаточно не доведено саме якого часу фортеця мається на увазі - римська фортеця Алектор, чи залишки джучидського міста кінця XIV-XV ст. Матеріальні залишки античного часу та середньовіччя зафіксовані під руїнами османської фортеці.

У 1990-ті рр. були проведені розвідки В.Б. Пиворовичем, завдяки яким поповнилася колекція нумізматичних знахідок. Продовження вивчення археологічного комплексу Тягиня протягом XX ст. та на початку XXI ст., безумовно, доповнили інформацію про цю пам'ятку, утім ці роботи мали епізодичний, нерегулярний характер. У 2009-2010 рр. тут проводили розкопки співробітники Національного заповідника «Хортиця» під керівництвом В.Є. Ільїнського (Ильинский, 2010: 308-313). В різних частинах городища були закладені чотири розкопи загальною площею $220 \mathrm{~m}^{2}$. Отримані результати засвідчили наявність різночасових культурних нашарувань. При цьому доволі значна частина монументальних будівельних об’єктів 3 вапняку та велика кількість артефактів датується XIV-XV ст. (Петрашина, 2011: 71-79). В той же час, на думку однієї з учасниць досліджень - В. Петрашиної, результати свідчать про фрагментарність отриманих даних, «адже вивчення обмеженої ділянки укріплень не дає повного уявлення про загальну фортифікаційну систему Великого князя Вітовта, татарські об'єкти, планування та інфраструктуру середньовічного міста о. Тягинь» (Петрашина, 2011: 79).

В. С. Ільїнський визначав час заснування Тягинської фортеці серединою XIV ст. і пов'язував його із діяльністю Великого князівства Литовського i Руського після перемоги над татарами у 1362 р. 3 метою укріплення кордонів та подальшого розвитку торгівельного шляху, так званого Татарського. Саме для того були побудовані укріплені містечка та таможні. Отже, за інтерпретацією автора, місто-фортеця Тягинь-Семимаяк було побудоване литовцями й існувало з 1363 по 1484 р.(Ильинский, 2010: 308, 310). 3 іншого боку, він не розглядав можливість існування городища золотоординського часу у попередній період .

На думку дослідника історичної географії Золотої Орди В. Л. Егорова, городище, відкрите В. І. Гошкевичем, є одним з чотирьох відомих татарських міст Нижнього Подніпров'я (Егоров, 1985: 12). Твердження В. Л. Егорова підтримав М. В. Сльніков (Сльніков, 2006: 45-51). Чотири поселення в Нижньому Подніпровї (Великі Кучугури, Таванське, «Конські води» та Тягинське), на яких виявлені укріплення, $€$ татарськими містами. Вони «знаходилися в місцях переправ та виконували роль сторожових охоронних пунктів». Щодо культурно-хронологічної належності городища, то М. В. Сльніков відзначає, що «кераміка, вироби з заліза та кістки Тягинського городища мають аналогії серед знахідок джучидських пам'яток ПівнічноЗахідного Причорномор'я, Криму, Закавказзя, Поволжя, давньоруських поселень Надпоріжжя» (Сльніков, 2006: 48). 
У 2017 р. нерушійні роботи на пам'ятці провів Д. Кобалія. Він здійснив

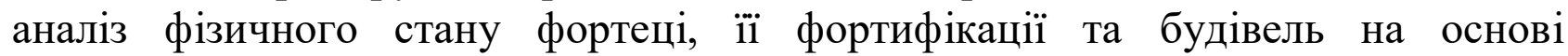
фотограмметричних замірів (Кобалія, 2018 :172-196). У якості вихідних даних він також використав результати та плани В. І. Гошкевича, інших дослідників. зокрема матеріали В. С. Ільїнського. За результатами ортофотозйомки виявлено до 108 аномалій, 68 з яких на території городища та замку. За спостереженнями Д. Кобалії замок мав не А-подібну форму, а складався з трьох рівних за площею секторів, верхівкою яких була квадратна вежа. Всі чотири оборонні лінії виходили до обривистого берега. Північний сектор мав в'їзд, який зберігся у вигляді вузького урвища, яке перетинав обривистий схил. На думку Д. Кобалії, тут могла бути ще одна вежа (точка 599). «3 півночі на захід до замку примикало ще декілька валів, які з'єднували його 3 трапецієподібним городищем. Вони могли виникнути в результаті багаторазової реконструкції, яку відмічав В. С. Ільїнський. Крім квадратної вежі замка на острові, ймовірно, існували ще дві - це так звана «північна вежа» та підвищення у північнозахідній частині острова» (Кобалія 2018: 184-185).

Тому встановлення реального становища пам'ятки, iї історії та значення у цивілізаційному процесі Північного Причорномор'я та України в цілому постало надзвичайно важливим завданням сучасного етапу історикоархеологічних досліджень. Це дослідження південної ділянки фортифікаційної діяльності Литовського князівства та ії особливостей. Надзвичайно важливими у цьому напрямку вивчення постали організація та проведення польових досліджень із створення доказової бази, яка на сьогодні є головним джерелом концептуальних побудов. Саме такі роботи були розпочаті у 2016 р. Південною Середньовічною експедицією Інституту археології НАНУ (керівник д.і.н., професор кафедри всесвітньої історії та методик навчання УДПУ С.О. Білясва) та продовжені у 2017-2021 pp. і відзначилися визначними відкриттями міжнародного значення.

Метою наших досліджень постало подальше вивчення південної ділянки фортифікаційної діяльності литовських князів за допомогою комплексних археологічних досліджень та залученням новітніх природничих методів та сучасного обладнання.

У викладі основного матеріалу доцільно виокремити емпіричну та теоретичну складову, які взаємопов'язані завданнями комплексних робіт.

Дослідження городища. У серпні 2016 р. Південна Середньовічна експедиція Інституту археології НАНУ (кер. С.О. Біляєва) розпочала обстеження території городища біля с. Тягинка Бериславського району Херсонської області (Біляєва та ін., 2017: 495-502).

За наявності спільних тенденцій історії та урбанізації Північного Причорномор'я, дослідження городища доцільно розглядати у загальній системі цивілізаційного розвитку регіону, враховуючи західний та східний вектор районування території. Отже, навіть апріорі, виникнення переправи, міста та фортеці, можливо, відбивають різні етапи історії поселення на острові Тягинка. Переправа, як місце можливого перетинання водойми, у даному випадку річки Дніпро, має природну основу і перспективу використання, як, 
приміром, і інші переправи, відомі за історичним контекстом. 3 середини XIII ст. і до середини XIV ст. ця територія входила до володінь Улусу Джучі, головним економічним напрямком якого був торговий.

Використання переправ, як вдалого місця торгівельних операцій (подібно до ситуації з Торговицею), чи морських портів (як у Аккермані та Кілії) було важливою передумовою формування та розвитку міста. Археологічні розкопки 2016 р. засвідчили наявність джучидського міста та городища, що підтверджується забудовою, 3 наявністю будівель культового характеру, характерними рисами міської культури: кераміка сграфіто XIV-XV ст. відкритих форм групи Східний Крим та Західний Крим (Тесленко, 2014: 495 512;541-560). Крім того це глазурована кераміка, система водопостачання та інші складові міської культури.

Отже, матеріальна культура Тягинського городища, принаймні ділянок розкопок 2016 p. i наступного року, абсолютно тотожна іншим золотоординським центрам. Як і квітучі портові міста, побудовані на торгових шляхах, Тягинь репрезентував місто із характерними рисами осередків Улусу Джучі та провінційно-візантійської культури, маючи широкі аналогії у матеріалах Північного Причорномор'я, зокрема Криму. Кавказу, Поволжжя. До того ж, за татарських часів Чорноморська торгівля потрапляє до рук італійських купців, генуезців, які засновують свої факторії. Після подій 1362 р. із встановленням влади Великого князівства Литовського та Руського до устя Дніпра і далі до Тавані (Івакін,1996: 282), мали місце певні заходи із розбудови мережі укріплень, зокрема фортеці Тавань (Івакін,1996: 205).

Вже у 2016 р. поблизу розкопу на поверхні знайдений залізний щитковий перстень із зображенням, яке нагадує вершника на коні, дещо схоже сюжетові погоні, що наводило на думку можливих подальших знахідок литовського культурного кола. Це знайшло своє підтвердження у артефактах розкопок 2017 р. На обох розкопах на території городища знайдені речі литовського походження - бронзова та залізна накладки на шкіряні гаманці, які мають аналогії у речовому комплексі Литви, зокрема у похованні могильника Діктарай (Urbanavićiene, 1995: 184, pav.35,1), що підтвердило литовську складову південного поясу укріплень. Крім того, були знайдені і інші речі, які, можливо, також мали литовське походження. Іншим важливим фактором було засвідчення проходження транснаціонального торгового шляху зі Сходу на Захід, наявності митниці та переправи, підтвердженням чого були знахідки татарських монет першої половини XV ст., у тому числі із контрамаркою Генуї, чекана Кафи. Аналогічні монетні знахідки були відомі і В.Б. Пиворовичу. Особливий інтерес представляла польська королівська монета 3 Кракова першої половини XV ст. Владислава Варненчика (1434-1444 рр.), що засвідчує західний напрям зв'язків. Отже, наявність міської забудови підтверджують думку В. Б. Сгорова та М. М. Сльнікова щодо існування великого татарського міста на Тягинському городищі, яке після занепаду міст у 60-70-ті роки XIV ст. продовжувало існувати у якості великого поселення біля фортець.

Надзвичайно важливим питанням у цьому напрямку постало продовження вивчення фортеці, iï структури, планування та матеріальної 
культури. Тому у 2018-2021 pр. розкопки були зосереджені на фортеці Тягинь.

Першочерговим завданням було визначення плану фортеці, отримання топографічного плану, вивчення хронологічної періодизації будівельних структур та збережених архітектурно-археологічних залишків фортифікації, окремих структур тощо. Завдяки аерофотозйомці за допомогою квадрокоптеру, проведеної О. В. Чубенко та М. М. Ієвлевим, топографічній зйомці, здійсненій О. В. Манігдою та О. В. Грабовською, вдалося отримати орто фотоплан фортеці Тягинь, встановити іiі планову структуру та окреслити можливі етапи розбудови. Вони дозволили встановити, що В. І. Гошкевичем були досліджені донжон та половина території. Як помітно на орто фото знімках, фортеця складається з декількох частин (На розі, 2018:31).

Перша секція фортеці за плануванням майже квадратної форми із довгим входом-брамою $з$ північного боку. Квадратна вежа (донжон), розкопана В. Гошкевичем, та територія навколо вежі, за вимірами В. Гошкевича, кожна стіна вежі дорівнює 9 м. Отже загальна площа ії дорівнює $81 \mathrm{~m}^{2}$.

Друга секція фортеці являє собою трапецію, вершина (чи верхній бік) якої складає 32,3 м (Північна стіна), а основа дорівнює 109,4 м. Західна стінка дорівнює 72,3 м, а східна - 66,1 м. Можливо, спочатку ця фортеця мала вигляд рівнобедренного трикутника (як фортеці Константинопольського типу), проте згодом була добудована ще одна частина (двір), або вона могла і відразу будуватися $з$ двох частин, а відтак також нагадувати трикутник $з$ донжоном.

Подальші пошуки зовнішньої стіни фортеці призвели до встановлення іiі протяжності вздовж краю підвищення по лінії розкопу. На сьогоді встановлено вже протяжність кладки стіни до 35 м. Стіна збереглася завширшки до 1,1 м, складена із вапняку класичним засобом: великі каміння по краях та забутовка посередині. Збереженість стіни різна, до 6 рядків. Крім того, відзначені підпорні стіни завширшки 0,5 м, довжиною 2,5 м, прибудовані до зовнішньої стіни 3 інтервалом біля 10 м. Поблизу зовнішньої стіни фортеці знайдені арбалетні болти та стріли, характерні для системи озброєння Литви XIV-XV ст. Повні аналогії болтам знайдені під час розкопок Високого замку у Вільнюсі (Виткунас, Забила, 2017: 75). Серед виробів з заліза та бронзи зустрічаються деяки речі, що мають аналогії у комплексах могильного інвентаря на території Литви. Але керамічний комплекс презентує матеріали, характерні для широкого простору володінь улусів Монгольської імперії та візантійськопричорноморських старожитностей Криму. Це керамічний посуд кухонного i столового використання 3 монохромною та поліхромною поливою, кераміка сграфіто. Деякі екземпляри останньої мають прокреслені літери із золоченням (?). Спроба історичної реконструкції ділянки Тягинської фортеці, запропонованої М.М. Ієвлевим, засвідчує схожі риси із Тракайською фортецею, а також деякі деталі, що нагадують будівельну традицію, застосовану у генуезькій фортеці Судак (На розі, 2018:с.38-39).

Роль Тягинської фортеці як митниці на переправі підтверджують і результати батиметричних досліджень, здійснених О.В. Чубенко та M.М. Ієвлевим, завдяки яким під водою знайдені залишки вежі, пристані та місця переправи (На розі, 2018: с.43-46). 
Аерофотозйомка дозволила виявити ще одну частину фортеці, яка перетинала iї загальний простір і формувала трапецієподібну структуру. Можливо, це та сама фортеця, яка була побудована Менглі Гіреєм наприкінці XV ст. на місті литовської фортеці Вітовта. Побічно це підтверджується і знахідкою двох груп срібних монет: джучидських - першої половини XV ст. та монет Кримського ханства останньої чверті XV ст. Крім того, про подальше існування певних структур пам'ятки, доля яких ще потребує подальших досліджень, свідчать окремі знахідки кримсько-татарської та польської монети Сигизмунда III 3 перфорацією (вторинного використання) XVI-XVII ст. на поверхні городища.

У 2020 р. була відкрита кутова вежа фортеці, прямокутна, розміром 7,0 мх4,5 м, загальною площею $31,5 \mathrm{~m}^{2}$, яка могла бути вежею на в'їзді у фортецю, або частиною головної брами фортеці. Верхня (можливо аркова) частина брами могла бути зруйнована. Стіни вежі складені з вапняку на вапняковому розчині, впущені у материк на глибину 0,4-0,6 м. Товщина стін 1,0-1,2 м. 3 зовнішнього боку заштукатурені та вкриті побілкою. Побілка i різного роду декоративні оздоблення стін були характерними i для інших замків Литви, Польщі, Скандинавії XIV-XVI ст.

Стіни збереглися на різну висоту, максимально до 1,75 м та до 12 рядків кладки. Кладка пастеліста, орфостатна, Північно-західний кут на висоті 0,3 м опоясаний фризом висотою 0,4 м, зробленим з цілого вапняку, прикрашеним різьбленим декором у сельджуцькому стилі. Аналогії відомі на пам'ятках Північного Причорномор'я, зокрема у Криму, наприклад на цитаделі Мангупа, XIV cт., на вході до мавзолею Джанике-Ханум першої половини XV ст. Знахідки каменів $з$ елементами схожого декору були відмічені ще під час досліджень В.І. Гошкевича. Стіна із вставкою піднімалася у висоту до 1 м, й можливо мала пройм або вікно (?), про що можливо свідчить досить рівне завершення стіни за допомогою пласких подовжених каменів вапняку. Після вставки із сельджуцьким декором частина стіни була також облицьована пласкими плитами розміром 0,4 м у висоту. Одна 3 плит мала паз, у який могла входити інша архітектурна деталь. За нею, частина стіни представляла кладку вапняків завширшки $0,8 \mathrm{~m}$ і висотою також на 0,4 м, за кладкою знов була оброблена плита висотою 0,4 м та завширшки 0,4 м. Під стіною, облицьованою плитами були розташовані два рядка досить великих вапнякових оброблених каменів, на які були вкладені плити облицювання. Розміри вапняків 0,60x0,20; 0,40x0,20 м. Вздовж стіни виявлена доріжка - вимощена 3 пласких каменів. Складається уявлення, що доріжка добре утоптана ще за часів функціонування вежі та фортеці взагалі. В той же час, стіна фундаментом, ймовірно, була заглиблена в материк, про що свідчать зондажі біля північної та східної стін. Вони виявили, що північна стіна була заглиблена у материк на 0,40 м, а східна стіна до 0,60-0,65 м, але біля решти стін вимощеної доріжки виявлено не було. Можливо деталі облицювання стіни були вторинного використання iз монументальної будівлі городища часів Улусу Джучі наприкінці XIII-XIV ст., i яке продовжило своє існування у наступні часи. Але для остаточного висновку потрібні вагомі докази з розкопок городища, яке ще не достатньо досліджене. 
У приміщенні вежі в північно-західній половині простежено залишки конструкції розміром 1 мх1,6 м з дерев'яних лаг (8 дошок), кожна завширшки до $14 \mathrm{~cm}$, які ймовірно були скріплені за допомогою цвяхів, знайдених під дошками на підлозі вежі. На дошках знайдено два фрагменти важкого залізного виробу. Вони були загладжені з одного кінця, довжиною 12 см, товщиною, що збереглася частково, 3 см та діаметром $22 \mathrm{~cm}$. Можливо, вони належать до бомбарди - артилерійської зброї XIV-XV ст. Після розчистки підлоги на глибині 1,6 м посередині приміщення по осі північ-південь виявлені три ями для стовпів, які підтримували верхній ярус вежі. Вони заглиблені у материк до 0,25 м., діаметр ям в середньому 0,3 м, у кожній присутні певні залишки трухлявої деревини, за периметром ями обмазані глиною. Стіни вежі складені 3 оброблених, або частково оброблених вапняків, 3 обох сторін кладки та заповнені бутом посередині. У зовнішньому профілі західної стіни кладка збереглася до 12 рядків.

У 2021 р. була відкрита частина східної стіни фортеці. Біля неї і у внутрішньому просторі фортеці були зроблені відкриття надзвичайного значення, які свідчать про синкретичність культури та причетність фортеці до різних цивілізаційних осередків. Тут була знайдена плита 3 геральдичним знаком, загальний вигляд якої свідчить про належність до християнського світу; капітель колони з сельджуцьким декором. Слід відзначити і знахідку залізної, кованої булави із заливкою свинцем. Навершя має форму перевернутої груші із завершенням конусоподібної форми. Збереглася і частина держака, також із заливкою свинцем. Це перша та найбільш рання знахідка у Північному Причорномор'ї.

Як відомо, булава мала подвійне призначення: як бойової зброї та символу влади гетьмана, полковника та кошового отамана. При цьому в історії зброї вона мала довгий шлях ще 3 первісного суспільства. За доби Київської Русі булава виконує функцію бойової та цивільної зброї (Гуцул, 2011: 143). Увійшла у комплекс рицарської збройної культури середньовічної Європи.

Схрещені парадні булави 3 округлим навершям прикрашають герб Великих гетьманів Литовських, перелік яких починається з 1497 р. гетьманом Костянтином Острозьким (1497-1500 pp.). 3 формуванням нового стану українського суспільства - козацтва - елементи рицарської культури були сприйняті та засвоєні рицарством України (Тоїчкін 2014: 232). Органічною складовою її постала й булава.

В комплексі монетних знахідок останніх років досліджень знов знайдені свідоцтва далеких торгівельних шляхів - вже друга монета польського короля Владислава Варненчика (1434-1444рp.), татарські монети кінця XIV ст., монети Менглі Гирея, парадна кераміка сграфіто, імпортний скляний посуд.

Перед нами частина фортифікаційної системи Вітовта, яка простягнулася від заходу на схід і включала кам'яні замкові фортеці, які відповідали новому етапу європейського замку.

Висновки. Дослідження 2016-2021 рр. довели надзвичайну важливість вивчення археологічних пам'яток українських земель доби середньовіччя у Північному Причорномор'ї. Знаковим відкриттям, визнаним українською та 
світовою спільнотою, постало створення доказової бази існування будівельних залишків фортеці Тягинь, архітектурно-археологічних об'єктів та ознак литовської присутності. Ї̈ї розташування на крайньому Півдні території Великого князівства Литовського та Руського уособлювало важливий форпост захисту українських земель, важливого чинника створення передумов становлення нового суспільного стану козацтва та його використання у захисті батьківщини. Як важливе історико-культурне та суспільно-політичне явище, фортеця Тягинь представляє значний інтерес для вивчення маловідомих сторінок доби середньовіччя: історії литовсько-руської державності, Кримського ханства, італійських міст - Генуї та Венеції на Чорному морі, контактів Османської імперії та українського козацтва. Всі ці визначні та доленосні часи української історії, безперечно, входять до актуальної тематики сьогодення і потребують подальшого вивчення.

\section{СПИСОК ВИКОРИСТАНИХ ДЖЕРЕЛ І ЛІТЕРАТУРИ}

Архів, 1854 - Архів історико-юридических сведений, относящихся до России, изд. Николаем Калачевым. М., 1854. кн. 2, 544 c.

Біляєва, Фіалко, Гуленко, 2017 - Біляєва С.О., Фіалко О.С. Гуленко К.С. Археологічні дослідження поселення біля с. Тягинка у 2016 р. // Нові дослідження пам'яток козаиьької доби в Украӥні. Вип. 26. 2017. С. $495-502$.

Виткунас, Забила, 2017 - Виткунас М., Забила Г. Городища балтов: неизвестное наследие. Bильнюс: Lietuvos archeologijos draugija, 2017, $88 \mathrm{c}$.

Гошкевич, 1916 - Гошкевич В.И. Раскопки на острове против м. Тягинки // Летопись музея за 1914 год. Херсон, 1916. Вып. 6. 48 с.

Гуцул, 2011 - Гуцул В.М. Рицарська мілітарна технологія в Києво-Руській та Польсько-Литовській державах у XIII-XVI ст.: інструменти, концепції та практики збройної боротьби: дис. канд. іст. наук: 07.00.02; Нац. ун-т «Києв.-Могилян. акад.». Київ, 2011. 306 с.

Дяченко, 2004 - Дяченко С.А. Левобережье Нижнего Днепра на карте Риччи Занони 1767 года // Наукові Записки. Проблеми археології, етнографії, літературознавства, мистецтвознавства, музеєзнавства, ономастики, соиіологіï. Херсон., Айлант. 2004. С. 54-71.

Егоров, 1985 - Егоров В.Л. Историческая география Золотой Орды. М., 1985. 246 с.

Енгель, 2014 - Енгель Й.Х. Історія України та українських козаків. Харків 2014. 640 с.

Єльников, 2006 - Сльников М. До питання про кількість золотоординських городищ на Нижньому Дніпрі // Північне Причорномор'я і Крим у добу середньовіччя (XIV-XVI cm.). Кіровоград. 2006. С. 45-51.

Жарких, 2017 - Жарких М. Натиск на південь: Три роки політики Вітовта (1397 - 1399 pp.), 2017. URL: https://www.m-zharkikh.name/en/History/Monographs/Essays/SourceValueGenealogies/Structure.html

Ильинский, 2010 - Ильинский В.Е. Город Тягинь-Семимаяк на Таванской переправе.(Историческая справка) // Заповідна Хортиия. Матеріали IV міжнародної науково-практичної конферениії «Історія запорозького козацтва: в пам'ятках та музейної практиці. Спеціальний випуск. Збірка наукових праць. Запоріжжя. 2010. C. 308-313.

Івакін, 1996 - Івакін Г.Ю. Історичний розвиток Києва ХІІІ-XV ст.: історико-топографічні нариси. К. 1996.271 с. Кобалія, 2018. - Кобалія Д. Крепость Тягинь и ее современное состояние // Scriptorium nostrum. 2018 . № 2 (11). c. $172-196$.

Красножон, 2018 - Красножон А.В. Фортеці та міста Північно-Західного Причорномор'я. Одеса: Видавництво Чорномор'я. 2018. 311 c.

На розі, 2018 - На розі двох світів. Історична спадщина України та Литви на території Херсонської області / Авт. кол.: С.О. Біляєва, К.С. Гуленко, О.С. Фіалко, М.М. Ієвлев, О.В. Грабовська, О.В. Манігда, О.В. Чубенко, О.В. Симоненко, О.С. Дзнеладзе, Д.М. Сікоза. НАН України. Інститут археології; ХМГО «Культурний центр Україна-Литва». Київ; Херсон: Гілея, 2018. 72 с.

Оленковская, Оленковский, 1978 - Оленковская М.И., Оленковский Н.П. Разведки на территории Херсонской области // Археологические открытия 1977 года. М., 1978. С. 364.

Петрашина, 2011 - Петрашина В. Археологічні дослідження Національного заповідника «Хортиця» на о. Тягинь 2010 р. (за матеріалами розкопу № 3) // Нові дослідження пам'яток козацької доби в Україні. 2011. Вип. 20. С. 71-79.

Тесленко, 2014 - Тесленко И.Б. Одна из гончарных традиций Таврики XIV-XV вв. (керамика группы ЮгоЗападного Крыма) // История и археология Крыма. Вып. 1. Симферополь. 2014. С. 495-512, 541-560.

Тихомиров, 1979 - Тихомиров М.Н. «Список русских городов дальних и ближних» // Русское летописание. M.,1979. C. 83-137. 
Тоїчкін, 2014 - Тоїчкін Д.В. Булави й перначі на теренах України: зброя та символ влади // Історія давньої зброї. Дослідження 2014: зб. наук. пр. Інститут історії Украӥни НАН Украӥни; Національний військовоісторичний музей Украӥни. Київ: Ін-т історії України НАНУ. 2014. С. 227-241.

Черная, 1998 - Черная Е.Д. Коллекция поливной керамики Херсонского краеведческого музея // Историкокультурные связи Причерноморья и Средиземноморья Х-ХVIII вв. По матеріалам поливной керамики. Тезисы докладов научной конференции. Симферополь, 1998. С. 186-189.

Шлапак, 2004 - Шлапак М. Белгород-Днестровская крепость. Исследование средневекового оборонного зодчества. Кишинев, 2004. 237 с.

Эварницкий, 1898 - Эварницкий Д.И. Вольности запорожских козаков. СПб., 1898. 427 с.

Яворницький, 1990 - Яворницький Д.І. Історія запорозьких козаків. У 3-х т. Т. 1 / Передмова В.А. Смолія; Ред. кол.: П.С. Сохань (голова), В.А. Смолій (заст. голови), В.Г. Сарбей, Г.Я. Сергієнко, М.М. Шубравська (відп. секр.). АН Української РСР. Археографічна комісія, Інститут історії. К.: Наукова думка, 1990. 596 с.

Urbanavićiene, 1995 - Urbanaviċiene S. Dictarų kapininas // Lietuvos archeologija. 1995. T. 11. C. 169-206.

\section{REFERENCES}

Arhiv, 1854 - Arhiv sctoriko-yuridichnyh svedeniy, otnosyaschihsya do Rossii, izd.Nikolaem Kalachovym. M., 1854. kn. 2., $544 \mathrm{~s}$ [in Russian]

Biliaieva, Fialko, Hulenko, 2017 - Biliaieva S.O., Fialko O.Ye. Hulenko K.S. Arkheolohichni doslidzhennia poselennia bilia s. Tiahynka u $2016 \mathrm{r}$. [Archaeological investigationsof the settlement andfortress tiagin: some resultsand problems] // Novi doslidzhennia pam'iatok kozatskoi doby v Ukraini. Vyp. 26. 2017. S. 495-502. [in Ukrainian]

Vytkunas, Zabyla, 2017 - Vytkunas M., Zabyla H. Horodyshcha baltov: neyzvestnoe nasledye [Fortified settlements of the Balts: unknown heritage]. Vylnius: Lietuvos archeologijos draugija, 2017. 88 s. [in Russian]

Hoshkevych, 1916 - Hoshkevych V.Y. Raskopky na ostrove protyv m. Tiahynky [Excavation on the island against Tyaginki] // Letopys muzeia za 1914 hod. Kherson, 1916. Vyp. 6. 48 s. [in Russian]

Hutsul, 2011 - Hutsul V.M. Knightly military technology in the Kyiv-Russian and Polish-Lithuanian states in the XIIIXVI centuries: tools, concepts and practices of armed struggle [Knightly military technology in the Kyiv-Russian and Polish-Lithuanian states in the XIII-XVI centuries: tools, concepts and practices of armed struggle]: dis. cand. ist. science: 07.00.02; Nat. Kyiv-Mohyla University acad. Kyiv, 2011. 306 p. [in Ukrainian]

Diachenko, 2004 - Diachenko S.A. Levoberezhe Nyzhneho Dnepra na karte Rychchy Zanony 1767 hoda [The left bank of the Lower Dnieper on the Ricci Zanoni map of 1767] // Naukovi Zapysky. Problemy arkheolohii, etnohrafii, literaturoznavstva, mystetstvoznavstva, muzeieznavstva, onomastyky, sotsiolohii. Kherson., Ailant. 2004. S. 54-71. [in Russian]

Ehorov, 1985 - Ehorov V.L. Ystorycheskaia heohrafyia Zolotoi Ordy [Historical geography of the Golden Horde]. M., 1985. 246 s. [in Russian]

Enhel, 2014 - Enhel Y.Kh. Istoriia Ukrainy ta ukrainskykh kozakiv [History of Ukraine and Ukrainian Cossacks]. Kharkov 2014. 640 s. [in Ukrainian]

Yelnykov, 2006 - Yelnykov M. Do pytannia pro kilkist zolotoordynskykh horodyshch na Nyzhnomu Dnipri [On the question of the number of Golden Horde settlements on the Lower Dnieper] // Pivnichne Prychornomor'ia i Krym u dobu serednovichchia (XIV-XVI st.). Kirovohrad. 2006. S. 45-51. [in Ukrainian]

Zharkykh, 2017 - Zharkykh . Natysk na pivden: Try roky polityky Vitovta $(1397-1399$ rr.) [The pressure on the south: Three years of Vytautas' policy (1397 - 1399)], 2017. URL: https://www.mzharkikh.name/en/History/Monographs/Essays/SourceValueGenealogies/Structure.html [in Ukrainian]

Ylynskyi, 2010 - Ylynskyi V.E. Horod Tiahyn-Semymaiak na Tavanskoi pereprave.(Ystorycheskaia spravka) [The city of Tyagin-Semimayak on the Tavan ferry. (Historical information)] // Zapovidna Khortytsia. Materialy IV mizhnarodnoi naukovo-praktychnoi konferentsii «Istoriia zaporozkoho kozatstva: v pam'iatkakh ta muzeinoi praktytsi. Spetsialnyi vypusk. Zbirka naukovykh prats. Zaporizhzhia. 2010. S. 308-313. [in Russian]

Ivakin, 1996 - Ivakin H.Yu. Istorychnyi rozvytok Kyieva KhIII-KhV st.: istoryko-topohrafichni narysy [Historical development of Kyiv in the XIII-middle of the XVI century]. K. 1996. 271 s. [in Ukrainian]

Kobaliia, 2018. - Kobaliia D. Krepost Tiahyn y ee sovremennoe sostoianye [Tyagin fortress and its current state] // Scriptorium nostrum. 2018. № 2 (11). s. 172-196. [in Russian]

Krasnozhon, 2018 - Krasnozhon A.V. Fortetsi ta mista Pivnichno-Zakhidnoho Prychornomor'ia [Fortress and cities of the North-Western Black Sea coast]. Odesa: Vydavnytstvo Chornomor'ia. 2018. 311 s. [in Ukrainian]

Na rozi, 2018 - Na rozi dvokh svitiv. Istorychna spadshchyna Ukrainy ta Lytvy na terytorii Khersonskoi oblasti [At the corner of two worlds. Historical heritage of Ukraine and Lithuania in the Kherson region] / Avt. kol.: S.O. Biliaieva, K.S. Hulenko, O.Ye. Fialko, M.M. Iievlev, O.V. Hrabovska, O.V. Manihda, O.V. Chubenko, O.V. Symonenko, O.S. Dzneladze, D.M. Sikoza. NAN Ukrainy. Instytut arkheolohii; KhMHO «Kulturnyi tsentr Ukraina-Lytva». Kyiv; Kherson: Hileia, 2018. 72 s. [in Ukrainian]

Olenkovskaia, Olenkovskyi, 1978 - Olenkovskaia M.Y., Olenkovskyi N.P. Razvedky na terrytoryy Khersonskoi oblasty [Exploration in the territory of the Kherson region] // Arkheolohycheskye otkrbtyia 1977 hoda. M., 1978. S. 364. [in Russian]

Petrashyna, 2011 - Petrashyna V. Arkheolohichni doslidzhennia Natsionalnoho zapovidnyka «Khortytsia» na o. Tiahyn 2010 r. (za materialamy rozkopu № 3) [Archaeological excavations of the Khortytsia National Reserve on Fr. Tyahyn 
2010 (according to excavation materials № 3)] // Novi doslidzhennia pam’iatok kozatskoi doby v Ukraini. 2011. Vyp. 20. S. 71-79. [in Ukrainian]

Teslenko, 2014 - Teslenko Y.B. Odna yz honcharnykh tradytsyi Tavryky XIV-XV vv. (keramyka hruppy YuhoZapadnoho Kryma) [One of the pottery traditions of Taurica XIV-XV centuries. (ceramics of the South-West Crimea group)] // Ystoryia y arkheolohyia Kryma. Vyp. 1. Symferopol. 2014. S. 495-512, 541-560. [in Russian]

Tykhomyrov, 1979 - Tykhomyrov M.N. «Spysok russkykh horodov dalnykh y blyzhnykh» [«List of Russian cities far and near»] // Russkoe letopysanye. M.,1979. S. 83-137. [in Russian]

Toichkin, 2014 - Toichkin D.V. Bulavy y pernachi na terenakh Ukrainy: zbroia ta symvol vlady [Maces and feathers on the territory of Ukraine: weapons and symbols of power] // Istoriia davnoi zbroi. Doslidzhennia 2014: zb. nauk. pr. Instytut istorii Ukrainy NAN Ukrainy; Natsionalnyi viiskovo-istorychnyi muzei Ukrainy. Kyiv: In-t istorii Ukrainy NANU. 2014. S. 227-241. [in Ukrainian]

Chernaia, 1998 - Chernaia E.D. Kollektsyia polyvnoi keramyky Khersonskoho kraevedcheskoho muzeia [Collection of glazed ceramics of the Kherson Museum of Local Lore] // Ystoryko-kulturnbe sviazy Prychernomoria y Sredyzemnomoria X-XVIII vv. Po materialam polyvnoi keramyky. Tezysы dokladov nauchnoi konferentsyy. Symferopol, 1998. S. 186-189. [in Russian]

Shlapak, 2004 - Shlapak M. Belhorod-Dnestrovskaia krepost. Yssledovanye srednevekovoho oboronnoho zodchestva [Belgorod-Dnestrovskaya fortress. Study of medieval defense architecture]. Kyshynev, 2004. 237 s. [in Russian]

Evarnickij, 1898 - Evarnickij D.I. Vol'nosti zaporozhskih kozakov [Liberties of the Zaporozhye Cossacks]. SPb., 1898. 427 s. [in Russian]

Yavornytskyi, 1990 - Yavornytskyi D.I. Istoriia zaporozkykh kozakiv. U 3-kh t [History of the Zaporozhian Cossacks. In 3 volumes]. T. 1 / Peredmova V.A. Smoliia; Red. kol.: P.S. Sokhan (holova), V.A. Smolii (zast. holovy), V.H. Sarbei, H.Ya. Serhiienko, M.M. Shubravska (vidp. sekr.). AN Ukrainskoi RSR. Arkheohrafichna komisiia, Instytut istorii. K.: Naukova dumka, 1990. 596 s. [in Ukrainian]

Urbanavićiene, 1995 - Urbanaviciene S. Dictarų kapininas // Lietuvos archeologija. 1995. T. 11. S. 169-206. [In Lithuanian]

УДК 94(477)323.32"1991/2020"

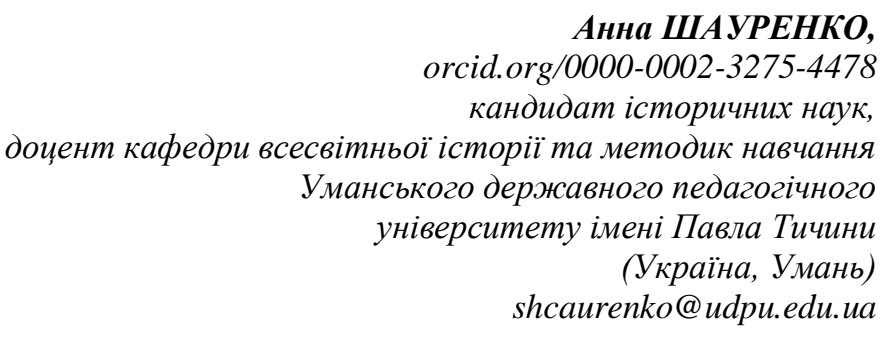

\section{ДОБРОБУТ СЕЛЯН У ПОСТРАДЯНСЬКИЙ ПЕРІОД}

У статті розглянуто особливості добробуту сільського населення у пострадянський період. Акцентується увага на забезпеченості населення необхідним для життя матеріальними благам. Насамперед, продуктами харчування, промисловими товарами, послугами та умовами, щчо задовольняють певну потребу людини $i$ відповідають ї̈ інтересам. У не найкращуму стані перебувала сочіальна сфера, комунальне господарство і медицина. Кризові явища, якими супроводжувалися трансформаційні процеси в економіці, завдали відчутних збитків матеріальному забезпеченню селян. За результатами зібраних матеріалів доведено, щзо економічна криза, швидкі темпи інфляиії, проблема дефіцитуу товарів, затримка коштів для виплати заробітної плати в 90-х рр. ХХ ст. ускладнювали матеріальне становище сільського населення України. Ключові слова. побут, селянство, матеріальний добробут, інфраструктура, медицина, культура, освіта.

Anna SHAURENKO

Candidate of Historical Sciences, Associate Docent of World History and methods of Teaching Uman State Pedagogical University Paul Tychiny

(Ukraine, Uman) shcaurenko@udpu.edu.ua 